\title{
Oxalis simplicifolia (Oxalidaceae), an unusual new unifoliolate species from the Marquesas Islands (French Polynesia)
}

\author{
David H. Lorence', Warren L. Wagner ${ }^{2}$ \\ I National Tropical Botanical Garden, 3530 Papalina Road, Kalaheo, HI $96741-95992$ Department of \\ Botany, MRC-166, Smithsonian Institution, P. O. Box 37012, Washington, DC 20013-7012) \\ Corresponding author: David H. Lorence (lorence@ntbg.org)
}

Academic editor: Viki Funk | Received 26 May 2010 | Accepted 15 June 2010 | Published 12 July 2011

Citation: Lorence DH, Wagner WL (2011) Oxalis simplicifolia (Oxalidaceae), an unusual new unifoliolate species from the Marquesas Islands (French Polynesia). In: Lorence DH, Wagner WL (Eds) Botany of the Marquesas Islands: new taxa, combinations, and revisions. PhytoKeys 4: 53-60. doi: 10.3897/phytokeys.4.1604

\begin{abstract}
Oxalis simplicifolia Lorence \& W. L. Wagner sp. nov., a new species from the Marquesas Islands (Ua Huka) is described and illustrated. It differs from the other Marquesas species, O. gagneorum, in having simple, unifoliolate glabrous leaves, minutely glandular-puberulent calyx lobes, shorter corolla lobes, erect capsules, and smaller seeds. As its habitat is under serious threat from human impact, feral animals, and weeds, we conclude this new species should be added to the IUCN Red List as critically endangered (CR).
\end{abstract}

\section{Keywords}

Conservation, French Polynesia, Marquesas Islands, Oxalis, Oxalidaceae, unifoliolate

\section{Introduction}

Intensive botanical exploration of the Marquesas Islands (French Polynesia) for the Vascular Flora of the Marquesas Islands and Flore de la Polynésie française projects has resulted in numerous additional new collections from these islands. During the collecting expeditions for the current Vascular Flora of the Marquesas Islands project under the direction of David H. Lorence and Warren L. Wagner (Wagner and Lorence, 1997) a unique unifoliolate species of Oxalis was collected on the island of Ua Huka by Steve Perlman and Ken Wood of the National Tropical Botanical Garden. An analysis 
of the conservation status of this new species reveals it should be included as a critically endangered (CR) species in the IUCN Red List.

Oxalis is a cosmopolitan genus of approximately 500 to 700 species with its greatest diversity in South America and the African Cape region (Mabberley 2008). Previously only a single native species of Oxalis was known from the Marquesas: O. gagneorum Fosberg \& Sachet, a small shrub $30-40 \mathrm{~cm}$ tall endemic to the islands of Eiao, Hiva Oa, Tahuata, and Fatu Hiva. The naturalized herbaceous species $O$. corniculata L. also occurs in suitable habitat on most of the main islands.

\section{Methodology}

All measurements given herein are taken from dried herbarium specimens, although certain features such as shapes were supplemented with information from alcoholpreserved flowers and fruits, field notes, and digital photos. Measurements are presented in the descriptions as follows: length $\times$ width, followed by units of measurement $(\mathrm{mm}$ or $\mathrm{cm})$. All specimens cited in this paper have been seen by the authors. The area of occupancy (distribution) for this species was calculated using herbarium collection data and field observations, and the conservation status is proposed following the IUCN Red List Category criteria (IUCN 2001; see also www.iucnredlist.org/info/ categories_criteria2001).

\section{Systematics}

\section{Oxalis simplicifolia Lorence \& W. L.Wagner, sp. nov.}

urn:Isid:ipni.org:names:77112690-1

http://species-id.net/wiki/Oxalis_simplicifolia

Figs 1, 2

Ad Oxalidem gagneorum Fosberg \& Sachet affinis sed in foliis simplicibus unifoliolatis glabris, in laminis ovatis vel late ovatis subpalmate nervatis, in lobis calycis minute glandulo-puberulis, in lobis corollae brevioribus 8-12 mm longis, in staminibus 5-8 mm longis, in capsulis maturis rectis et in seminis minoribus 0.8-0.9 $\times 0.5 \mathrm{~mm}$ differt.

Type. MARQUESAS ISLANDS: Ua Huka: Hanahouua valley, back of valley below cliff walls, 457 m elevation, $8^{\circ} 54.47^{\prime} \mathrm{S}, 139^{\circ} 30.89^{\prime} \mathrm{W}, 26$ June 2004, S. Perlman \& K. R. Wood 19072 (holotype: PTBG-041184!; Isotypes: P!, PAP!, US!).

Description. Perennial woody herbs or subshrubs $20-50 \mathrm{~cm}$ tall, stems prostrate or sprawling to erect, branching from near base, with sparse lateral branches, glabrous or new growth sparsely pilose, mature twigs $2-3 \mathrm{~mm}$ diam, bark smooth, reddish brown to dark brown, with tufts of pilose hairs at thickened, persistent leaf bases. Leaves simple, spirally arranged; blade dark green above, yellow-green below, firm and moderately coriaceous when fresh, chartaceous when dry, glabrous, (15-) 20-47 × (12-)18-37 mm 


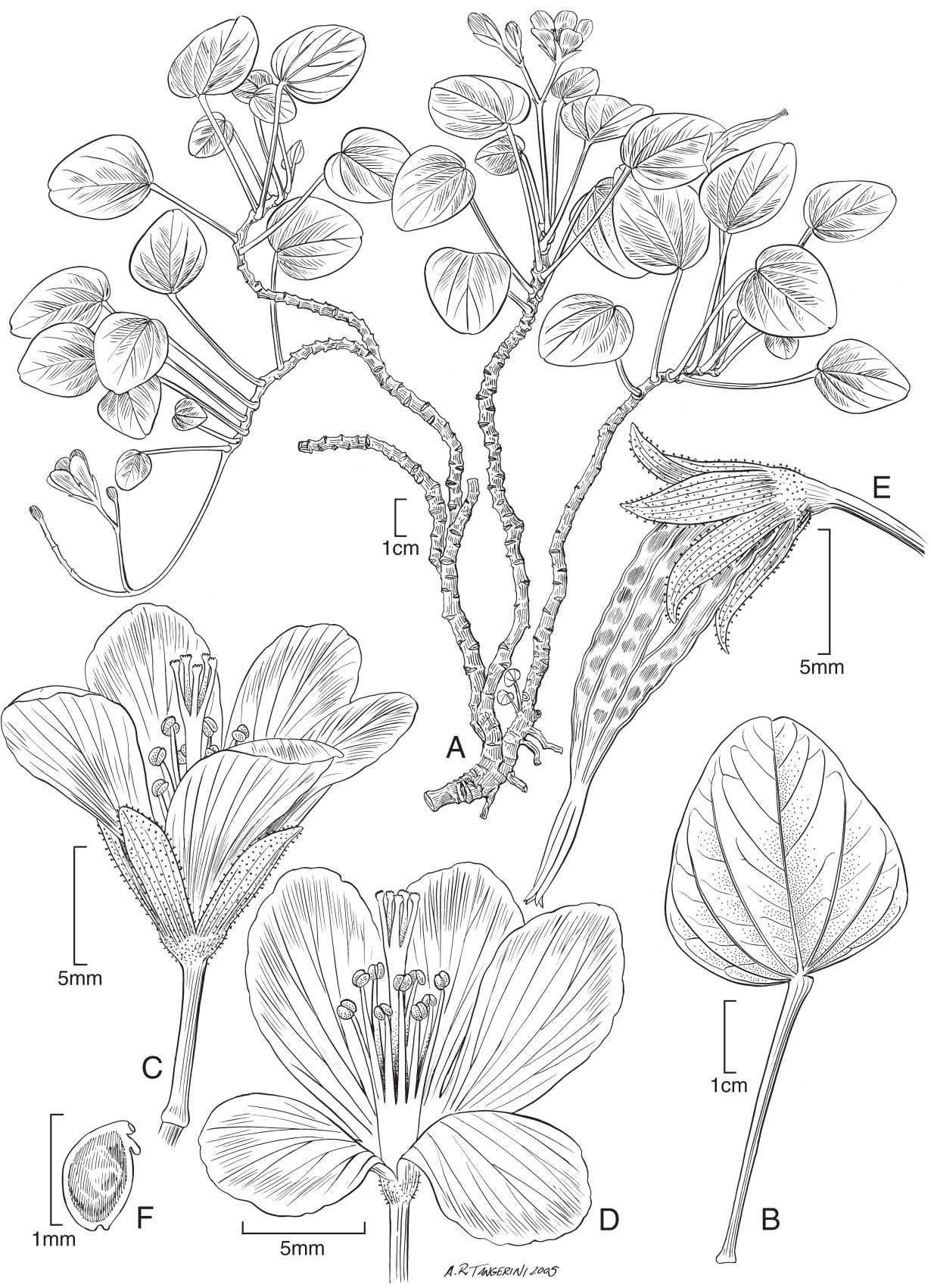

Figure I. Oxalis simplicifolia Lorence \& WL Wagner A habit B leaf C, D flowers $\mathbf{E}$ fruit $\mathbf{F}$ seed. Drawn from the type collection (Perlman \& Wood 10972) and field images. 


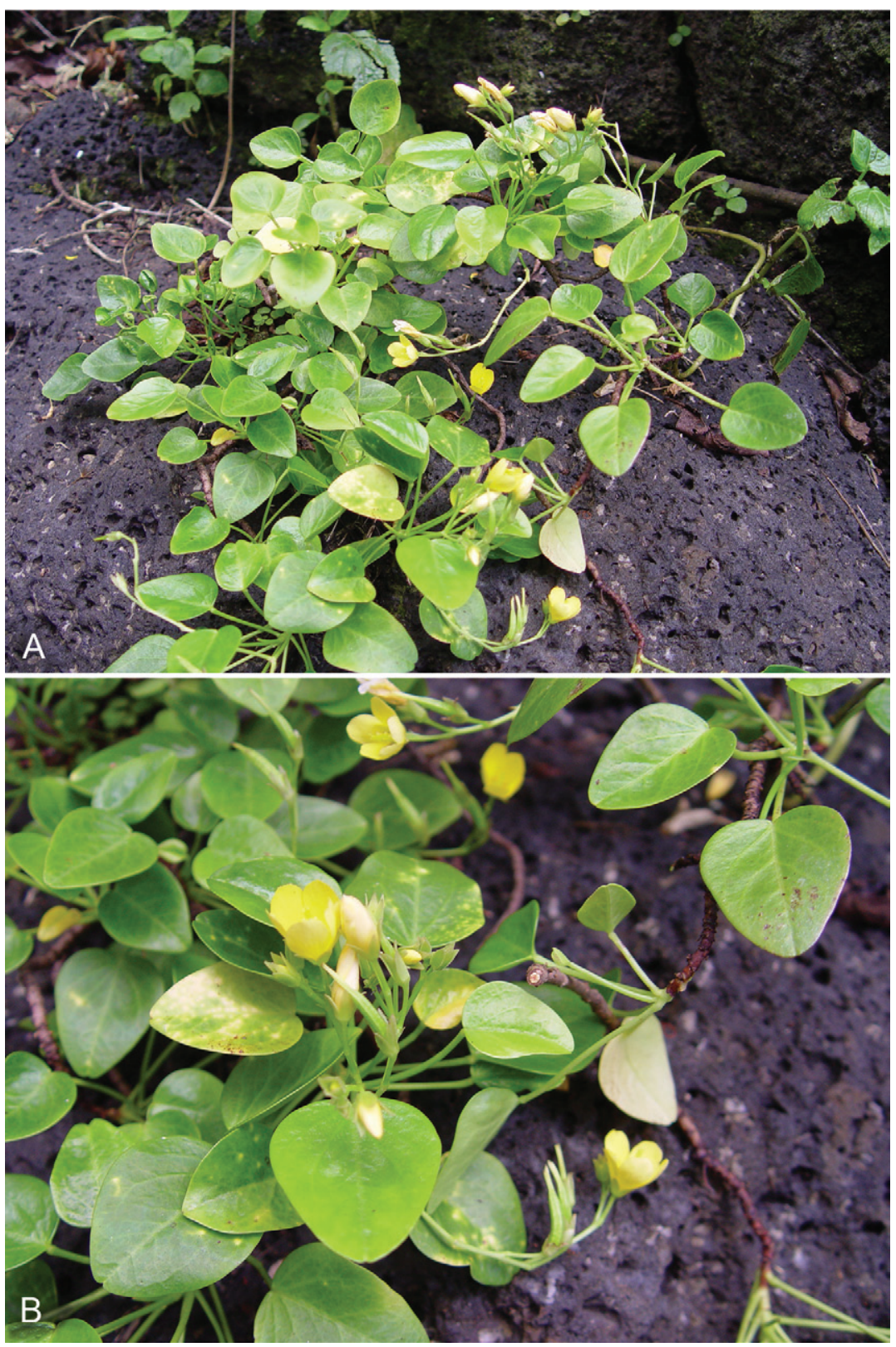

Figure 2. Field images of Oxalis simplicifolia A habit B stems with flowers and fruits (Perlman \& Wood 10972).

ovate to broadly ovate, base obtuse to rounded or truncate, apex obtuse, tip usually emarginate, venation subpalmate with 1-2(-3) pairs of secondary veins from base and 2-3 pairs along midrib above, venation raised and visible to $3^{\circ}$ above and to $4^{\circ}$ beneath; margin thin, plane; petiole $(20-) 25-45 \times 0.6-0.8 \mathrm{~mm}$, sparsely scattered pilose or gla- 
brescent, flattened, adaxially sulcate, distally with slight pulvinus. Inflorescences axillary near ends of branches, cymose, 5-13-flowered, 5-8 cm long, peduncles 4-5 cm long, terminating in apical flower and two monochasial lateral branches $18-40 \mathrm{~mm}$ long each with 2-6 flowers, bracts linear-subulate, $1-2 \times 0.3-0.4 \mathrm{~mm}$, sparsely puberulent with acicular and scattered glandular-tipped trichomes. Flowers (long-styled morph seen) with 5 calyx lobes 5-7 × 1.7-2 mm, narrowly ovate-oblong, 6-8-veined, apex acute, both surfaces minutely glandular-puberulent with capitate trichomes; petals yellow, 10-12 $\times 5 \mathrm{~mm}$, narrowly obovate to oblong-elliptic, 7-9-veined, apex obtuse to rounded; stamens 10 , in two series, the longer 7-8 $\mathrm{mm}$ long, the shorter $5.5-6 \mathrm{~mm}$ long, filaments connate basally, anthers broadly ellipsoid, $0.4-0.5 \mathrm{~mm}$ long, reniform to subcircular; gynoecium 10-14 mm long, with ovary 6-7 mm long, narrowly ovoid-cylindrical, externally glabrous, beak 4-5 mm long, styles 5, 1-2.5 mm long, stigmas slightly thickened, papillose, not bifid. Fruits ovoid-cylindrical, 10-11 $\times 2-2.5 \mathrm{~mm}$, at maturity apparently straight and not twisting, externally glabrous, carpels 5 , villous within, seeds ca. 40 . Seeds ellipsoid, compressed, $0.8-0.9 \times 0.5 \mathrm{~mm}$, surface shiny, brown, rugose.

Distribution. Known only from Ua Huka, Marquesas Islands.

Ecology. Known only from two localities on Ua Huka, this new species occurs in shrubby and herbaceous vegetation on vertical basalts cliff above a mesic to wet lowland forest zone with Freycinetia impavida (Gaudich. ex Hombr.) B.C. Stone, Hibiscus tiliaceus L., Pandanus tectorius Parkinson, and Pisonia grandis R. Br. Plants grow scattered on cliffs rooting in rock crevices (Figure 2A, B). Oxalis gagneorum occurs sympatrically or nearly so with $O$. simplicifolia at both Hanahouua (Perlman and Meyer 19748) and Hane/Hokatu (Wood \& Meyer 10530, 10551).

Etymology. The specific epithet refers to the simple, unifoliolate leaves.

Conservation status. Following the criteria and categories of IUCN (2001) Oxalis simplicifolia is assigned a preliminary status of Critically Endangered (CR): B2a, B2b (i-iii); D): B2: total area of occupancy less than $10 \mathrm{~km}^{2}$ (ca. $5 \mathrm{~km}^{2}$ ). B2a, two populations known; b (i-iii), habitat continuing decline inferred. D, population estimated to number fewer than 250 individuals. The suitable habitat for Oxalis simplicifolia on Ua Huka (ca. $83 \mathrm{~km}^{2}$ ) is indicated as an endangered environment, threatened by feral animals and invasive plants, reducing the extent of the forest. Estimated population size is ca $100+$ plants at the Hanahouua locality (Perlman \& Meyer 19748), and "scattered" individuals were noted by the collectors at the Hane/Hokatu locality (Wood \& Meyer 10530, 10551).

Specimens examined. Marquesas Islands: Ua Huka: Hanahouua valley, back of valley on ridge between Hanahouua and Hanalei, $8^{\circ} 54.47^{\prime} \mathrm{S}, 139^{\circ} 30.87^{\prime} \mathrm{W}, 488 \mathrm{~m}, 28$ July 2005, S. P. Perlman, J.-Y. Meyer 19748 (PTBG); Hane/Hokatu cliff, zone, 520 m, 11 Dec 2003, K. R. Wood, J.-Y. Meyer 10512 (PAP, PTBG, US).

Discussion. Although the majority of Oxalis species have palmately compound leaves with three (rarely to nine) leaflets, several taxa with unifoliolate leaves occur in South America in subgenus Thamnoxys (Lourteig 1994). At least three South African taxa are also unifoliolate: Oxalis monophylla L., Oxalis salteri L.Bolus, and Oxalis flava L. var. unifoliolata Dreyer \& Oberl. (Dreyer et al. 2010). These are small, bulbous, 
acaulescent plants with white or yellow flowers apparently unrelated to O. simplicifolia. Certain species, e.g. O. renifolia Kunth and a few other South American taxa can have one and three leaflets on the same branch (E. Emshwiller, pers. comm. 2009). Following Lourteig's $(1994,2000)$ monograph O. simplicifolia keys to subgenus Monoxalis (leaves simple, 1-foliolate, stigmas linguiform) which consists of two herbaceous species from the southwestern United States and Mexico $(O$. dichondrifolia A. Gray and $O$. robusta Kunth), neither of which bears any morphological similarity to $O$. simplicifolia.

This new species may be related to the Marquesas endemic O. gagneorum, from which it differs by its glabrous simple, unifoliolate leaves with ovate to broadly ovate blades having subpalmate venation of one to three basal vein pairs, minutely glandular puberulent calyx lobes, shorter corolla lobes 8-12 mm long, shorter stamens 5-8 mm long, capsules not twisting at maturity (they often twist in O. gagneorum), and smaller seeds $0.8-0.9 \times$ $0.5 \mathrm{~mm}$ (Table 1). Fosberg and Sachet (1981: 3-5, Fig. 1) stated that the relationships of $O$. gagneorum were obscure and suggested that it may be related to $O$. novaecalidoniae

Table I. Distinguishing morphological features of Oxalis gagneorum and O. simplex.

\begin{tabular}{l|l|l}
\hline Character & O. gagneorum & O. simplicifolia \\
\hline Height $(\mathrm{m})$ & $0.3-1.2$ & $0.2-0.5$ \\
\hline Stem pubescence & young growth pilose & glabrous or sparsely pilose \\
\hline Leaflet pubescence & pilose-strigose below & glabrous \\
\hline Leaflet number & 3 & 1 \\
\hline Leaflet shape & $\begin{array}{l}\text { broadly obovate or oblong- } \\
\text { elliptic }\end{array}$ & ovate to broadly ovate \\
\hline Leaflet blade length $(\mathrm{mm})$ & 35 & $(20-)$ 25-47 \\
\hline Leaf blade width $(\mathrm{mm})$ & 26 & $(12-) 18-37$ \\
\hline Venation & pinnate & subpalmate \\
\hline Secondary vein pairs & $5-7$ & $1-2(-3)$ basal, 2-3 above \\
\hline Flowers per inflorescence & $3-5$ & $5-13$ \\
\hline Calyx lobe shape & ovate & ovate-oblong \\
\hline Calyx lobe length $(\mathrm{mm})$ & $4-6$ & $5-7$ \\
\hline Calyx lobe width $(\mathrm{mm})$ & $2-3$ & $1.7-2$ \\
\hline Calyx pubescence & sparsely pilose & minutely glandular puberulent \\
\hline Corolla lobe length $(\mathrm{mm})$ & $12-35$ & $8-12$ \\
\hline Corolla lobe width $(\mathrm{mm})$ & $3-5$ & 5 \\
\hline Corolla lobe shape & $\begin{array}{l}\text { narrowly obovate to spathulate, } \\
\text { clawed }\end{array}$ & narrowly obovate to oblong-elliptic \\
\hline Shorter stamen length $(\mathrm{mm})$ & $11-14$ & $5-5.6$ \\
\hline Longer stamen length $(\mathrm{mm})$ & $14-16$ & $7-8$ \\
\hline Fruit shape & $\begin{array}{l}\text { Broadly cylindrical, twisting at } \\
\text { maturity }\end{array}$ & $\begin{array}{l}\text { Ovoid-cylindrical, not twisting at } \\
\text { maturity }\end{array}$ \\
\hline Fruit length $(\mathrm{mm})$ & $9-15$ & $10-11$ \\
\hline Fruit width $(\mathrm{mm})$ & $3-4$ & $2-2.5$ \\
\hline Seed length $(\mathrm{mm})$ & $1.3-1.4$ & $0.8-0.9$ \\
\hline Seed width $(\mathrm{mm})$ & $0.8-1.2$ & 0.5 \\
\hline Seed surface & shiny, brown, rugose & shiny, brown, rugose \\
\hline & & \\
\hline
\end{tabular}


Kunth \& Schlechter, a species belonging to section Caledonicae (= section Neocalidonicae), but that mature seeds were needed for more accurate placement. Lourteig (2000) placed O. gagneorum in section Rhombifoliae along with several neotropical species characterized by "lianoid" transversely striate stems [a character not apparent in material of either Marquesan species studied by us] and trifoliolate leaves with oblong to rhomboidal leaflets and lacking stipules, but expressed doubt as to its relationships due to the poor material available for study (i.e., lacking stigmas and seeds). Unfortunately, it has not been possible to obtain DNA sequences from samples of either Marquesan species thus far (E. Emshwiller, pers. comm. 2009), and consequently their phylogenetic relationships remain unclear.

Oxalis species often have different floral morphs, frequently tristylous or sometimes distylous (Weller et al. 2007). Examination of material of $O$. gagneorum revealed most flowers appear to be homostylous with styles about equaling the stamens. Due to a paucity of flowering collections of $O$. simplicifolia, only the long-styled floral morph with both whorls of stamens shorter than the style is known (illustrated in Fig. 1). There may be several possible explanations for this: either $O$. simplicifolia might be a clonally reproducing species with a single morph (as are several Oxalis species in Mexico), or it could be an autogamous species that reproduces sexually but has only a single morph (S. Weller, pers. comm. 2009). Further collections and field studied are clearly necessary to resolve this question.

\section{Acknowledgments}

This study was greatly facilitated by field observations, photos, and specimens provided by Ken Wood and Steve Perlman (National Tropical Botanical Garden) as part of the Vascular Flora of the Marquesas Islands project, which was supported by a generous private donation. We are grateful to Jean-Yves Meyer and staff of the Délégation à la Recherche (Papeete, Tahiti), the Musée de Tahiti et des Iles, and the Service du Développement Rural for logistic support, the Délégation for permission to collect in the Marquesas and the Délégation and the Haut-Commissariat de la République en Polynésie française for permission to conduct research. The illustration was skillfully drawn by Alice Tangerini (Smithsonian Institution). We thank Eve Emshwiller and Stephen Weller for reviewing the manuscript and useful discussions and Harold Robinson for translating the Latin diagnosis. The contribution by WLW to this study was partially supported by the Smithsonian Research Opportunities Fund and while appointed as McBryde Chair at the National Tropical Botanical Garden.

\section{References}

Dreyer LL, Oberlander KC, Roets F (2010) Reassessment of the taxonomic status of Oxalis fabaefolia (Oxalidaceae) and the description of a unique variety of Oxalis flava from the Northern Cape Province of South Africa. Blumea 55: 253-258. 
Fosberg FR, Sachet M-H (1981) Polynesian Plant Studies 6-18. Smithsonian Contributions to Botany 47: 1-38. doi: 10.5479/si.0081024X.47

IUCN (2001) IUCN Red List categories (version 3.1). IUCN Species Survival Commission, Gland, Switzerland.

Lourteig A (1994) Oxalis L. Subgénero Thamnoxys (Endl.) reiche emend. Lourt. Bradea 7(1): $1-199$.

Lourteig A (2000) Oxalis L. Subgéneros Monoxalis (Small) Lourt., Oxalis y Trifidus Lourt. Bradea 7(2): 201-371.

Mabberley DJ (2008) Mabberley's Plant-Book. Cambridge University Press.

Wagner WL, DH Lorence (1997) Studies of Marquesan Vascular Plants: Introduction. Allertonia $7:$ :221-225.

Weller SG, Domínguez CA, Molina-Freaner FE, Fornoni J, LeBuhn G (2007) The evolution of distyly from tristyly in populations of Oxalis alpine (Oxalidaceae) in the Sky Islands of the Sonoran Desert. American Journal of Botany 94: 972-985. doi: 10.3732/ajb.94.6.972 